\title{
PSYCHOMETRIC PROPERTIES OF THE BRIEF SYMPTOM INVENTORY IN A CLINICAL AND NONCLINICAL SAMPLE
}

\author{
Biljana Blazhevska Stoilkovska ${ }^{*}$, Katerina Naumova* \\ Institute of Psychology, Faculty of Philosophy, \\ Ss. Cyril and Methodius University in Skopje
}

\begin{abstract}
The aim of this study is to investigate the proposed factor structure, reliability, and discriminant validity of the Macedonian translation of one of the most widely used screening and outcome measures. Both samples are drawn from two separate data sets. The clinical sample ( $N=149,57 \%$ female) is composed of outpatients / participants, currently in use or in need of mental health services, formally diagnosed by psychiatrists and/or psychologists through a structured diagnostic clinical interview. All diagnoses were made in adherence to ICD-10 criteria. The nonclinical sample ( $\mathrm{N}=180,55 \%$ female) is composed of participants not meeting diagnostic criteria for any mental disorder or not needing/using mental health services in the previous six months. Confirmatory factor analysis was applied to examine the construct validity of the BSI. The results supported the original nine-factor structure in both samples, demonstrating acceptable model fit. Internal consistency of the overall BSI was high. Discriminant validity was explored by comparing the clinical and nonclinical sample on nine symptom dimensions and three global psychological distress indices. As found, the BSI differentiates between the two groups with respect to all dimensions and global indices. The study results indicate good psychometric properties of the BSI in Macedonian context.
\end{abstract}

Keywords: Brief Symptom Inventory, factorial structure, discriminant validity

\footnotetext{
* Both authors contributed equally to the manuscript and share first authorship.

1 e-mail: biljanab@fzf.ukim.edu.mk
} 
The Brief Symptom Inventory (BSI) is one of the most widely used multidimensional self-report instruments for the assessment of psychological symptoms. It has been utilised both for screening, as well as for evaluation of treatment outcomes with various clinical populations in different cultures (Derogatis, 2017; Derogatis \& Fitzpatrick, 2004). However, since the initial investigation of its factor structure (Derogatis \& Melisaratos, 1983), the evidence is inconclusive, as to whether the BSI can accurately measure nine dimensions of psychopathology or if it is a unidimensional measure of general psychological distress. In the past three decades, over two dozen factor analytic studies of the BSI have demonstrated factor variance across samples. It is worth noting that in most of these studies the results were obtained from different types of exploratory factor analytic procedures (EFA) rather than from confirmatory factor analysis (CFA).

When Derogatis and Melisaratos (1983) originally tested the hypothetical structure of the instrument they used principal components analysis (PCA) with varimax rotation to analyse data from a large sample of psychiatric outpatients. Seven of the nine conceived symptom constructs were reproduced (psychoticism, somatization, depression, hostility, paranoid ideation, obsessive-compulsive, phobic anxiety). The eight factor (anxiety) was split into two well-defined clinical components (panic, anxiety, and nervous tension), while the ninth (interpersonal sensitivity) did not replicate, probably due to the small number of items (only four). The nine factors accounted for $44 \%$ of the explained variance.

Subsequent studies with clinical samples did not find support for this factorial solution. For example, one factor structure was derived from PCA in a relatively homogeneous sample of forensic psychiatric inpatients and outpatients (Boulet \& Boss, 1991), as well as in adolescent and adult psychiatric inpatients, the latter mostly diagnosed with affective disorders (Piersma et al., 1994). Benishek et al. (1998) found one and two-factor solutions in a sample of substance abusers entering a treatment program using principal axis factoring (PAF) with oblimin rotation, while the unidimensional model was supported by CFA with fit indices below acceptable.

Among delinquent adolescents in detention, Whitt \& Howard (2012) derived a six-factor structure by PAF with oblimin rotation and confirmed it by maximum likelihood (ML) CFA. A modified version of this model was supported by CFA in a sample of adult men under criminal justice involvement (Valera et al., 2014).

In patients with spinal cord injuries, a six-factor solution was obtained from PCA with oblique rotation and ML estimation (Heinrich \& Tate, 1996), revealing specific components of distress related to traumatic injury and physical illness. Similarly, in a sample of primary care attenders, Schwannauer \& Chetwynd (2007) 
applied ML with oblique rotation and detected six-factors dominated by a single distress factor, while a series of CFAs in a sample of clinical psychology patients in the same study supported a three-factor model. Finally, eight factors, highly overlapping the original factor solution, were extracted from PCA with varimax rotation in a sample of intellectually disabled participants (Kellet et al, 2004).

Equivocal results have also been reported in nonclinical community samples. Hayes (1997) derived a six-factor model using PAF with oblimin rotation in college and university counselling centre population. Likewise, in a study by Holden et al. (2000)supported by CFA, three dimensions were extracted in university undergraduates using PCA with varimax rotation. When comparing Indian and Canadian university samples with multidimensional scaling, Watson and Sinha (1999) not only found rather similar two dimensional solutions in both cultures, they also found distinctive expressions of certain symptom dimensions, emphasizing the necessity of developing national norms for psychopathology measures.

Since then, factor-analytic investigations of cultural adaptations of the BSI have multiplied. For example, Ruipérez et al. (2001) extracted a six-factor solution from PCA with oblimin rotation in a nonclinical adult sample in Spain, while Pereda et al. (2007) found the original nine-factor solution in Spanish college students better than a unidimensional model. However, they used a different translation and CFA with elliptic robust least squares. Furthermore, a unidimensional solution was derived from PCA with oblimin rotation in a nonclinical adult sample in Greece (Loutsiou-Ladd et al., 2008).

In two separate analyses with large clinical samples, Printz et al. $(2008,2013)$ report insufficient model fit of the original structure when investigating the German translation. Contrary to these findings, in a large community sample representative of the population of Hungary, Urban et al. (2014), using a series of CFA's found that the original nine-factor model had an acceptable fit. Similarly, CFA on data from three separate representative Ukrainian general population surveys (Sereda \& Dembitskyi, 2016) also support the original internal structure of the Ukrainian and Russian translations used in the studies. Kabát et al. (2018) also report a sufficient fit of the original model using data from an adult sample representative of the Czech population. However, taking into consideration the ordinal response scale of the BSI and the expected non-normal distribution of data when measuring psychopathology, these last three studies have appropriately used the diagonally weighted least squares method (DWLS) to estimate the parameters of the CFAs.

Findings from Asian and African cultures are sparse yet mixed. Daoud and Abojedi (2010) report on a unidimensional invariate model extracted from PCA with 
oblique rotation in nonclinical and clinical samples from Jordan, while Raghavan et al. (2015) report on configural invariance of a two-factor model extracted from PCA with oblimin rotation, across three groups of torture survivors from Tibet, West Africa, and India.

Recently, the second order and bifactor model have received increasing attention. Cross-ethnic measurement invariance using multiple-group CFA in individuals treated for severe and persistent mental illness (Hoe \& Brekke, 2008) supported a secondary factor model, where the nine BSI subscales were indicators of a common factor. Utilising multidimensional item response theory with archival clinical data, Thomas (2012) found that the bifactor model slightly outperformed the original model, while both outperformed the unidimensional model. The bifactor model has also shown superior fit in CFA studies with community samples (Malloy-Diniz et al., 2020; Urban, 2014).

In light of the existing variations in factor structure across samples, the aims of this study are to (a) use confirmatory factor analysis to determine the factor structure of the Macedonian translation of the BSI in a clinical and nonclinical sample, and (b) examine the reliability and discriminant validity of the BSI.

\section{Method}

\section{Participants and procedure}

The participants are drawn from two separate data sets (Naumova, 2008; Naumova \& Naumov, 2019). The clinical sample ( $N=149$, 57\% female, $M_{\text {age }}=34.3$ years \pm 13.8 ) is composed of outpatients formally diagnosed by psychiatrists $(70 \%)$ and participants using or in need of professional mental health care $(30 \%)$ diagnosed by psychologists through a structured diagnostic clinical interview (MINI, Sheehan et al., 1998). All diagnoses were made in adherence to ICD-10 criteria: anxiety disorders $48.3 \%$, mood disorders $18.1 \%$, stress-related $16.1 \%$ and other disorders $17.4 \%$ (psychotic, conduct, personality and psychoactive substance use). The nonclinical sample $\left(N=180,55 \%\right.$ female, $M_{\text {age }}=35.1$ years \pm 12.9$)$ is composed of participants not meeting diagnostic criteria for any mental disorder (69.4\%) or not needing/using professional mental health care in the previous six months (30.6\%). The samples do not differ significantly regarding age or gender. All participants provided informed consent and completed the BSI as part of an extensive psychological assessment.

\section{Instrument}

The Brief Symptom Inventory (Derogatis \& Melisaratos, 1983) consists of 53 items measuring nine symptom dimensions: somatization (distress from perceptions of 
bodily dysfunction), obsessive-compulsive (unwanted, unremitting and irresistible thoughts and impulses), interpersonal sensitivity (feelings of personal inadequacy and inferiority), depression (dysphoric mood and affect, lack of motivation and loss of interest in life), anxiety (nervousness, tension and panic), hostility (anger revealing thoughts, feelings or actions), phobic anxiety (irrational and persistent fear response to places, objects or situations), paranoid ideation (projective thoughts, suspiciousness, grandiosity and delusions), and psychoticism (social alienation to symptoms of schizophrenia). Four items reflecting vegetative and other symptoms are not included in the subscales, since they are related to several, but are not unique to any specific dimension. Responses are given on a 5-point scale indicating degrees of distress "over the past 7 days including today", ranging from 0 (not at all) to 4 (extremely). Three global indices can also be calculated: (a) the General Severity Index (GSI), measuring overall distress; (b) the Positive Symptom Total (PST) is the count of reported symptoms; and (c) the Positive Symptom Distress Index (PSDI), measuring symptom severity, adjusted for the number of experienced symptoms.

The BSI was translated into Macedonian and adapted by the second author and a senior colleague as part of an international research project on mental health outcomes in people exposed to war stressors (Priebe et al., 2004).

\section{Results}

Descriptive statistics for somatization, obsessive-compulsive, interpersonal sensitivity, depression, anxiety, hostility, phobic anxiety, paranoid ideation, and psychoticism, as well as GSI, PST, and PSDI in both samples, are summarized in Table 1.

As can be seen, psychoticism and phobic anxiety symptoms were rated as least distressing in both samples. In line with the prevalence of diagnosed disorders in the clinical sample, anxiety symptoms are most pronounced in this group, followed by obsessive-compulsive and depression symptoms, while the participants in the nonclinical sample reported paranoid ideation and anxiety as most frequently experienced symptoms.

\section{Factorial validity}

In order to test the nine first-order factors of the BSI Confirmatory factor analysis (CFA) was performed. Due to sample sizes, the ordinal response scale, and multivariate non-normality, the weighted least squares mean, and variance adjusted (WLSMV) method was used for parameter estimation. This estimator was chosen since it is more accurate than the well-known maximum likelihood (ML) when the assumption of multivariate normality is not met (Li, 2016). As suggested by Kline (2016), model fit was assessed by the following goodness of fit indices - $\chi^{2}$ 
test statistic, comparative fit index (CFI), root mean square error of approximation (RMSEA), and standardized root mean square residual (SRMR). Criteria for good model fit are CFA $\geq 0.95$, RMSEA $\leq 0.06$, and SRMR $\leq 0.08$ (Hu \& Bentler, 1999). If the older guidelines for the model fit, i.e. CFA $\geq 0.90$, RMSEA $\leq 0.10$, and SRMR $\leq 0.10$ are not met, then the model is not acceptable (Weston \& Gore, Jr., 2006). Accordingly, CFA between 0.90 and 0.95, RMSEA between 0.06 and 0.10, and SRMR between 0.08 and 0.10 indicate acceptable fit of the estimated model.

Table 1. Descriptive statistics of BSI symptom dimensions and global indices

\begin{tabular}{|c|c|c|c|c|c|c|c|c|c|}
\hline & Sample & $\mathrm{N}$ & $\mathrm{M}$ & SD & Mdn & Min. & Max. & Skewness & Kurtosis \\
\hline \multirow[t]{2}{*}{ Somatization } & clinical & 149 & 1.16 & .91 & 1.00 & 0.00 & 3.86 & .49 & -.63 \\
\hline & nonclinical & 180 & .48 & .55 & .28 & 0.00 & 2.29 & 1.25 & .81 \\
\hline \multirow{2}{*}{$\begin{array}{l}\text { Obsessive- } \\
\text { compulsive }\end{array}$} & clinical & 149 & 1.54 & 1.04 & 1.33 & 0.00 & 3.83 & .37 & -.95 \\
\hline & nonclinical & 180 & .58 & .64 & .33 & 0.00 & 3.17 & 1.34 & 1.46 \\
\hline \multirow{2}{*}{$\begin{array}{l}\text { Interpersonal } \\
\text { sensitivity }\end{array}$} & clinical & 149 & 1.30 & .96 & 1.25 & 0.00 & 3.75 & .50 & -.74 \\
\hline & nonclinical & 180 & .35 & .59 & 0.00 & 0.00 & 3.00 & 2.20 & 5.16 \\
\hline \multirow[t]{2}{*}{ Depression } & clinical & 149 & 1.41 & 1.00 & 1.33 & 0.00 & 3.83 & .53 & -.62 \\
\hline & nonclinical & 180 & .40 & .54 & 0.17 & 0.00 & 3.33 & 2.34 & 7.31 \\
\hline \multirow[t]{2}{*}{ Anxiety } & clinical & 149 & 1.75 & .99 & 1.50 & 0.00 & 4.00 & .47 & -.61 \\
\hline & nonclinical & 180 & .67 & .64 & 0.50 & 0.00 & 3.33 & 1.37 & 2.25 \\
\hline \multirow[t]{2}{*}{ Hostility } & clinical & 149 & 1.11 & .93 & 1.00 & 0.00 & 3.80 & .88 & -.01 \\
\hline & nonclinical & 180 & .48 & .60 & 0.40 & 0.00 & 4.00 & 2.56 & 9.29 \\
\hline \multirow{2}{*}{$\begin{array}{l}\text { Phobic } \\
\text { anxiety }\end{array}$} & clinical & 149 & 1.00 & .91 & .80 & 0.00 & 3.80 & 1.02 & .37 \\
\hline & nonclinical & 180 & .23 & .37 & 0.00 & 0.00 & 2.60 & 2.68 & 10.85 \\
\hline \multirow{2}{*}{$\begin{array}{l}\text { Paranoid } \\
\text { ideation }\end{array}$} & clinical & 149 & 1.40 & .89 & 1.20 & 0.00 & 4.00 & .54 & -.25 \\
\hline & nonclinical & 180 & .69 & .62 & 0.60 & 0.00 & 2.60 & 0.99 & .61 \\
\hline \multirow[t]{2}{*}{ Psychoticism } & clinical & 149 & .95 & .82 & 0.80 & 0.00 & 3.00 & .67 & -.60 \\
\hline & nonclinical & 180 & .20 & .40 & 0.00 & 0.00 & 2.40 & 2.54 & 7.31 \\
\hline \multirow[t]{2}{*}{ GSI } & clinical & 149 & 1.30 & .73 & 1.13 & 0.15 & 3.19 & .60 & -.50 \\
\hline & nonclinical & 180 & .46 & .42 & .33 & 0.00 & 2.30 & 1.68 & 3.35 \\
\hline \multirow[t]{2}{*}{ PST } & clinical & 149 & 31.07 & 11.82 & 32.00 & 4.00 & 51.00 & -.20 & -.76 \\
\hline & nonclinical & 180 & 14.34 & 11.08 & 11.00 & 0.00 & 46 & .97 & .04 \\
\hline \multirow[t]{2}{*}{ PSDI } & clinical & 149 & 2.12 & .55 & 2.06 & 1.16 & 3.64 & .38 & -.38 \\
\hline & nonclinical & 180 & 1.60 & .47 & 1.57 & 0.00 & 4.00 & .95 & 3.62 \\
\hline
\end{tabular}

CFA results obtained on the clinical sample (Table 2) demonstrated that CFI was higher than 0.90 (slightly below 0.95) and SRMR was below 0.08, indicating acceptable model fit. The value below 0.05 of the RMSEA $(90 \%$ CI[0.022, 0.040] denoted good fit of the model. WLSMV $\chi^{2}$ was statistically significant, revealing that the observed and predicted covariance matrices differ significantly. It should be noted that this fit statistic is liberal when variables are not normally distributed (http://davidakenny.net/cm/fit.htm) and when strong correlation exists among the observed variables (Kline, 2016). Hence, there is a possibility for many Type I 
errors. In addition, it is based on the proposition of exact fit, while reporting on reasonable fit is adequate as well (Brown, 2006). Factor loadings ranged from 0.89 to 0.38 (all statistically significant at $p<.001$ ). Considering all four fit indices, the BSI model observed here could be considered acceptable.

As shown in Table 2, CFA revealed adequate fit of the BSI model in the nonclinical sample. Specifically, WLSMV $\chi^{2}$ was not statistically significant indicating that there is no difference among the observed data and the predicted model. The CFI was 0.90 and SRMR was slightly above 0.08 revealing that the model fit is acceptable. RMSEA was lower than 0.05 with $90 \%$ CI[0.000, 0.028] denoting good fit of the model. Factor loadings ranged from 0.84 to 0.14 showing that two items' loadings were not statistically significant.

Table 2. Goodnes-of-fit indices for the nine-factor model of the BSI

\begin{tabular}{lccccc}
\hline Model & WLSMV $\chi^{2}$ & df & CFI & SRMR & RMSEA (90\% CI) \\
\hline Clinical sample & $1254.92^{* *+}$ & 1091 & 0.94 & 0.07 & $0.03[0.02,0.04]$ \\
Nonclinical sample & 1159.91 & 1091 & 0.90 & 0.09 & $0.02[0.00,0.03]$ \\
\hline
\end{tabular}
$p<.001$

\section{Discriminant validity}

Considering that the BSI dimensions were not normally distributed, the Mann-Whitney U test was employed to explore discriminant validity of BSI. Differences in GSI and all nine symptom dimensions between the clinical and nonclinical sample were analysed.

Results showed that participants in the clinical group had significantly higher scores on all symptom dimensions, as well as on all global indices (Table 3). These findings confirm the discriminant validity of the BSI.

\section{Reliability}

Reliability of the scale and subscales was estimated using Cronbach alpha internal consistency coefficient. Overall reliability of the BSI in the clinical and nonclinical sample was high ( $\alpha=.96$ and $\alpha=.95$, respectively). Cronbach's alpha coefficients for separate BSI symptom dimensions in the clinical sample ranged from 0.86 for anxiety and depression to 0.70 for interpersonal sensitivity. Reliability of BSI symptom dimensions in the nonclinical sample ranged from $\alpha=.82$ for obsessive-compulsive and interpersonal sensitivity to $\alpha=.56$ for phobic anxiety. All reliability coefficients are presented in Table 4. 
Table 3. Results of the Mann-Whitney U test: differences in BSI symptom dimensions and global indices between the clinical and nonclinical sample

\begin{tabular}{|c|c|c|c|c|c|c|}
\hline \multicolumn{2}{|l|}{ Sample } & $\mathrm{N}$ & Mean Rank & Sum of Ranks & $\mathrm{U}$ & $\mathrm{Z}$ \\
\hline \multirow[t]{2}{*}{ Somatization } & clinical & 149 & 206,34 & 30745,00 & 7250,000 & $-7,22^{* * *}$ \\
\hline & nonclinical & 180 & 130,78 & 23540,00 & & \\
\hline \multirow{2}{*}{$\begin{array}{l}\text { Obsessive- } \\
\text { compulsive }\end{array}$} & clinical & 149 & 216,33 & 32233,50 & 5761,500 & $-8.95^{\star \star \star}$ \\
\hline & nonclinical & 180 & 122,51 & 22051,50 & & \\
\hline \multirow{2}{*}{$\begin{array}{l}\text { Interpersonal } \\
\text { sensitivity }\end{array}$} & clinical & 149 & 222,06 & 33087,50 & 4907,500 & $-10,14^{* * *}$ \\
\hline & nonclinical & 180 & 117,76 & 21197,50 & & \\
\hline \multirow[t]{2}{*}{ Depression } & clinical & 149 & 223,29 & 33269,50 & 4725,500 & $-10,20^{* \star *}$ \\
\hline & nonclinical & 180 & 116,75 & 21015,50 & & \\
\hline \multirow[t]{2}{*}{ Anxiety } & clinical & 149 & 223,93 & 33366,00 & 4629,000 & $-10,25^{* \star *}$ \\
\hline & nonclinical & 180 & 116,22 & 20919,00 & & \\
\hline \multirow[t]{2}{*}{ Hostility } & clinical & 149 & 205,39 & 30603,50 & 7391,500 & $-7,07^{\star \star \star \star}$ \\
\hline & nonclinical & 180 & 131,56 & 23681,50 & & \\
\hline \multirow[t]{2}{*}{ Phobic anxiety } & clinical & 149 & 218,68 & 32583,00 & 5412,000 & $-9,57^{\star \star \star}$ \\
\hline & nonclinical & 180 & 120,57 & 21702,00 & & \\
\hline \multicolumn{2}{|c|}{ Paranoid ideation clinical } & 149 & 208,67 & 31092,00 & 6903,000 & $-7,61^{* * *}$ \\
\hline & nonclinical & 180 & 128,85 & 23193,00 & & \\
\hline \multirow[t]{2}{*}{ Psychoticism } & clinical & 149 & 221,42 & 32991,00 & 5004,000 & $-10,26^{* * *}$ \\
\hline & nonclinical & 180 & 118,30 & 21294,00 & & \\
\hline \multirow[t]{2}{*}{ GSI } & clinical & 149 & 230,49 & 34343,00 & 3652,000 & $-11,36^{* * *}$ \\
\hline & nonclinical & 180 & 110,79 & 19942,00 & & \\
\hline \multirow[t]{2}{*}{ PST } & clinical & 149 & 227,09 & 33837,00 & 4158,000 & $-10,78^{\star \star \star *}$ \\
\hline & nonclinical & 180 & 113,60 & 20448,00 & & \\
\hline \multirow[t]{2}{*}{ PSDI } & clinical & 149 & 213,32 & 31784,00 & 6211,000 & $-8,38^{* * *}$ \\
\hline & nonclinical & 180 & 125,01 & 22501,00 & & \\
\hline
\end{tabular}

$\overline{* * \star} p<.001$

Table 4. Internal consistency coefficients of the BSI symptom dimensions and GSI

\begin{tabular}{lccc}
\hline & & Clinical sample & Nonclinical sample \\
\hline BSI dimensions & N of items & Cronbach's alpha & Cronbach's alpha \\
\hline Somatization & 7 & & .77 \\
Obsessive-compulsive & 6 & .84 & .82 \\
Interpersonal sensitivity & 4 & .86 & .82 \\
Depression & 6 & .70 & .78 \\
Anxiety & 6 & .86 & .80 \\
Hostility & 5 & .86 & .76 \\
Phobic anxiety & 5 & .82 & .56 \\
Paranoid ideation & 5 & .74 & .64 \\
Psychoticism & 5 & .74 & .67 \\
GSI & 53 & .74 & .95 \\
\hline
\end{tabular}


Descriptive, reliability, and nonparametric tests were performed in SPSS 24.0. The CFA analyses were conducted with the Lavaan package (Rosseel, 2012) in R environment (R Core Team, 2020).

\section{Discussion}

Our analysis confirmed the Macedonian BSI factor structure, as proposed by Derogatis and Melisaratos (1983), both in clinically diagnosed adults as well as in a community sample. More precisely, the original model fit the data adequately in the clinical sample. The majority of items had satisfactory factor loadings $>.60$, while only a few items had loadings between .45 and .55 and only one had a loading slightly below .40. Accordingly, most of the items shared at least $36 \%$ of the variance with the factors, thus providing support for the conclusion regarding the model fit, i.e. classification of the measured psychopathology symptoms into nine groups as predicted.

In addition, the reliability coefficients of all subscales, i.e. somatization, obsessive-compulsive, interpersonal sensitivity, depression, anxiety, hostility, phobic anxiety, paranoid ideation, and psychoticism varied from acceptable to very good, representing satisfactory internal consistency. Taken together, both analyses proved the psychometric characteristics of the BSI, namely its construct validity and reliability in the clinical sample.

Findings obtained from the nonclinical sample suggested that the BSI model could be considered acceptable, although several constraints were registered in our analyses, such as small factor loadings on several items, and lower Cronbach's alpha coefficients for three subscales (phobic anxiety, paranoid ideation and psychoticism). However, due to the varying manifestation of psychological distress in the general population as opposed to in defined clinical populations, prior to item or subscale modification, additional confirmatory factor analysis is advised with larger urban and educationally more diverse community samples.

The Mann-Whitney U test revealed that BSI subscales and global indices distinguish participants in the clinical sample from those in the nonclinical sample. That is, all nine symptom dimensions, overall distress, number of reported symptoms, and level of their severity were higher among clinically diagnosed individuals, thus confirming the discriminant validity of the BSI.

Our findings are in line with recent studies that have also used robust CFA estimators (Kabát et al., 2018; Sereda \& Dembitskyi, 2016; Urban et al., 2014) lending further evidence to the notion that previously reported variations in the factorial structure of the BSI could result to a greater degree from the use of less powerful 
and methodologically diverse factor analytic procedures, rather than from inherent instability of the original BSI model (Loutsiou-Ladd et al., 2008).

An additional strength of our study is both the use of a clinically diagnosed sample and the diagnostic screening of the nonclinical group, thus eliminating potential threats to the discriminant validity of the measure resulting from often undetected yet increased psychological distress or treatment involvement in community samples (Thurston et al., 2008).

\section{Conclusion}

In this study, the nine-factor structure of the BSI examined using CFA was reproduced in both clinical and non-clinical samples thus demonstrating its construct validity. In addition, the study results confirmed its discriminant validity and internal consistency. The exception was found to be the phobic anxiety subscale in the nonclinical sample.

Second-order and bifactor models of the BSI could be investigated in future studies. Confirmed psychometric characteristics of the Macedonian translation of the BSI justify its application both in research and clinical settings. The results are particularly important since this is an easily administered self-report measure of psychological status that can be utilized for screening, assessment, and treatment outcomes in various clinical populations. 


\section{References}

Benishek, L. A., Hayes, C. M., Bieschke, K. J., \& Stöffelmayr, B. E. (1998). Exploratory and confirmatory factor analyses of the Brief Symptom Inventory among substance abusers. Journal of Substance Abuse, 10(2), 103-114. https://doi.org/10.1016/S0899-3289(99)80127-8

Boulet, J., \& Boss, M. W. (1991). Reliability and validity of the Brief Symptom Inventory. Psychological Assessment: A Journal of Consulting and Clinical Psychology, 3(3), 433-437. https://doi.org/10.1037/1040-3590.3.3.433

Brown, T. A. (2006). Confirmatory Factor Analysis for applied research. The Guilford Press.

Daoud, F. S., \& Abojedi, A. A. (2010). Equivalent factorial structure of the Brief Symptom Inventory (BSI) in clinical and nonclinical Jordanian populations. European Journal of Psychological Assessment, 26(2), 116-121. https://doi.org/10.1027/1015-5759/a000016

Derogatis, L. R. (2017). Symptom Checklist-90-Revised, Brief Symptom Inventory, and BSI-18. In M. E. Maruish (Ed.), Handbook of psychological assessment in primary care settings (p. 599-629). Routledge/Taylor \& Francis Group.

Derogatis, L. R., \& Fitzpatrick, M. (2004). The SCL-90-R, the Brief Symptom Inventory (BSI), and the BSI-18. In M. E. Maruish (Ed.), The use of psychological testing for treatment planning and outcomes assessment: Instruments for adults (p. 1-41). Lawrence Erlbaum Associates Publishers.

Derogatis, L. R., \& Melisaratos, N. (1983). The Brief Symptom Inventory: An introductory report. Psychological Medicine, 13(3), 595-605. https://doi. org/10.1017/S0033291700048017

Hayes, J. A. (1997). What does the Brief Symptom Inventory measure in college and university counseling center clients? Journal of Counseling Psychology, 44(4), 360-367. https://doi.org/10.1037/0022-0167.44.4.360

Heinrich, R. K., \& Tate, D. G. (1996). Latent variable structure of the Brief Symptom Inventory in a sample of persons with spinal cord injuries. Rehabilitation Psychology, 41(2), 131-147. https://doi.org/10.1037/00905550.41.2.131

Hoe, M., \& Brekke, J. S. (2008). Cross-ethnic measurement invariance of the Brief Symptom Inventory for individuals with severe and persistent mental illness. Social Work Research, 32(2), 71-78. https://doi.org/10.1093/ $\operatorname{swr} / 32.2 .71$

Holden, R. R., Starzyk, K. B., McLeod, L. D., \& Edwards, M. J. (2000). Comparisons among the Holden Psychological Screening Inventory (HPSI), the Brief Symptom Inventory (BSI), and the Balanced Inventory 
of Desirable Responding (BIDR). Assessment, 7(2), 163-175. https://doi. org/10.1177/107319110000700208

Hu, L.-t., \& Bentler, P. M. (1999). Cutoff criteria for fit indexes in covariance structure analysis: Conventional criteria versus new alternatives. Structural Equation Modeling, 6(1), 1-55.

Kabát, J., Kaščáková, N., Fürstová, J., Bartůš-Ková, L., Glogar, P., Šolcová, I. P., \& Tavel, P. (2018). Psychometrické charakteristiky české verze stručného inventáře přiznaků (BSI-53) [Psychometric characteristics of the Czech version of the Brief Symptom Inventory (BSI -53)]. Československá Psychologie: Časopis Pro Psychologickou Teorii a Praxi, 62, 19-39.

Kellett, S., Beail, N., Newman, D. W., \& Hawes, A. (2004). The factor structure of the Brief Symptom Inventory: Intellectual disability evidence. Clinical Psychology \& Psychotherapy, 11(4), 275-281. https://doi.org/10.1002/cpp.410

Kenny, D. A. (2020, June 5). Measuring Model Fit. http://davidakenny.net/cm/fit. htm

Kline, R. B. (2016). Principles and Practice of Structural Equation Modeling (4th ed.). The Guilford Press

Li, C. (2016). Confirmatory factor analysis with ordinal data: Comparing robust maximum likelihood and diagonally weighted least squares. Behavior Research Methods, 48, 936- 949. https://doi.org/10.3758/s13428-015-0619-7

Loutsiou-Ladd, A., Panayiotou, G., \& Kokkinos, C. M. (2008). A Review of the factorial structure of the Brief Symptom Inventory (BSI): Greek Evidence. International Journal of Testing, 8(1), 90-110. https://doi. org/10.1080/15305050701808680

Malloy-Diniz, L., de Oliveira Serpa, A. L., de Souza Costa, D., Pinheiro, M. I. C., Diaz, A. P., de Paula, J. J., Miranda, D. M., \& Silva, A. G. (2020). Brief Symptoms Inventory psychometric properties supports the hypothesis of a general psychopathological factor. [Preprint]. PsyArXiv. https://doi. org/10.31234/osf.io/7jk2r

Naumova, K. (2008). Traumatskite iskustva, mentalnoto zdravje i kvalitetot na zhivot kaj licata koi dozhiveale voeni stresovi [Traumatic experiences, mental health, and quality of life in individuals exposed to war stressors] (Unpublished master's thesis). Ss. Cyril and Methodius University in Skopje.

Naumova, K., \& Naumov, F. (2019). [Unpublished raw data on cognitive, emotional and personality factors in a clinical and nonclinical sample].

Pereda, N., Forns, M., \& Peró, M. (2007). Dimensional structure of the Brief Symptom Inventory with Spanish college students. Psicothema, 19(4), 634-639. 
Piersma, H. L., Boes, J. L., \& Reaume, W. M. (1994). Unidimensionality of the Brief Symptom Inventory (BSI) in adult and adolescent inpatients. Journal of Personality Assessment, 63(2), 338-344. https://doi.org/10.1207/ s15327752jpa6302_12

Priebe, S., Gavrilović-Janković, J., Schützwohl, M., Galeazzi, M. G., Lečić-Toševski, D., Ajduković, D., Francikovic, T., Kucukalic, A. \& Popovski, M. (2004). Study of long-term clinical and social outcomes after war experiences in ex-Yugoslavia: Methods of the 'CONNECT'project. Psihijatrija danas, 36(1), 101-110.

Prinz, U., Nutzinger, D.O., Schulz, H., Petermann, F., Braukhaus, C., \& Andreas, S.(2008). Die Symptom Checkliste 90-R und ihre kurzversionen: Psychometrische analysen bei patienten mit psychischen erkrankungen [The Symptom Check List 90-R and their short versions in patients with mental disorders]. Physikalische Medizin, Rehabilitationsmedizin, Kurortmedizin, 18(6), 337-343. https://doi.org/10.1055 / s-0028-1093323

Prinz, U., Nutzinger, D. O., Schulz, H., Petermann, F., Braukhaus, C., \& Andreas, S. (2013). Comparative psychometric analyses of the SCL-90-R and its short versions in patients with affective disorders. BMC Psychiatry, 13(1), 104. https://doi.org/10.1186/1471-244X-13-104

R Core Team (2020). R: A language and environment for statistical computing. $\mathrm{R}$ Foundation for Statistical Computing.

Raghavan, S. S., Rosenfeld, B., \& Rasmussen, A. (2015). Measurement invariance of the Brief Symptom Inventory in survivors of torture and trauma. Journal of Interpersonal Violence, 32(11), 1708-1729. https://doi. org/10.1177/0886260515619750

Rosseel, Y. (2012). lavaan: An R Package for Structural Equation Modeling. Journal of Statistical Software, 48(2), 1-36.

Ruipérez, M. Á., Ibáñez, M. I., Lorente, E., Moro, M., \& Ortet, G. (2001). Psychometric properties of the Spanish version of the BSI. European Journal of Psychological Assessment, 17(3), 241-250. https://doi. org/10.1027//1015-5759.17.3.241

Schwannauer, M., \& Chetwynd, P. (2007). The Brief Symptom Inventory: A validity study in two independent Scottish samples. Clinical Psychology \& Psychotherapy, 14(3), 221-228. https://doi.org/10.1002/cpp.539

Sereda, Y., \& Dembitskyi, S. (2016). Validity assessment of the Symptom Checklist SCL-90-R and shortened versions for the general population in Ukraine. BMC Psychiatry, 16(1), 300. https://doi.org/10.1186/s12888-0161014-3 
Sheehan, D. V., Lecrubier, Y., Sheehan, K. H., Amorim, P., Janavs, J., Weiller, E., Hergueta, T., Baker, R., \& Dunbar, G. C. (1998). The Mini-International Neuropsychiatric Interview (M.I.N.I.): The development and validation of a structured diagnostic psychiatric interview for DSM-IV and ICD-10. The Journal of Clinical Psychiatry, 59 (Suppl 20), 22-57.

Thomas, M. L. (2012). Rewards of bridging the divide between measurement and clinical theory: Demonstration of a bifactor model for the Brief Symptom Inventory. Psychological Assessment, 24(1), 101-113. https://doi.org/10.1037/ a0024712

Thurston, I.B., Curley, J., Fields, S., Kamboukos, D., Rojas, A., \& Phares, V. (2008). How nonclinical are community samples? Journal of Community Psychology, 36(4), 411-420. https://doi.org/10.1002/jcop.20223

Urbán, R., Kun, B., Farkas, J., Paksi, B., Kökönyei, G., Unoka, Z., Felvinczi, K., Oláh, A., \& Demetrovics, Z. (2014). Bifactor structural model of symptom checklists: SCL-90-R and Brief Symptom Inventory (BSI) in a non-clinical community sample. Psychiatry Research, 216(1), 146-154. https://doi. org/10.1016/j.psychres.2014.01.027

Valera, P., Fullilove, R., Cali, S., Nunes, E., Chiongbian, V., Clark, W., \& Covey, L. (2015). The psychometric properties of the Brief Symptom Inventory in men under criminal justice involvement: Implications for forensic social workers in practice settings. British Journal of Social Work, 45(7), 22102223. https://doi.org/10.1093/bjsw/bcu074

Watson, D. C., \& Sinha, B. K. (1999). A cross-cultural comparison of the Brief Symptom Inventory. International Journal of Stress Management, 6(4), 255264. https://doi.org/10.1023/A:1021940321129

Weston, R., \& Gore, P. (2006). A brief guide to Structural Equation Modeling. The Counseling Psychologist, 34(5), 719-751.

Whitt, A., \& Howard, M. O. (2012). Brief Symptom Inventory factor structure in antisocial adolescents: Implications for juvenile justice. Research on Social Work Practice, 22(2), 166-173. https://doi.org/10.1177/1049731511418786 


\title{
ПСИХОМЕТРИСКИ КАРАКТЕРИСТИКИ НА КРАТКИОТ ИНВЕНТАР НА СИМПТОМИ КАЈ ИСПИТАНИЦИ ОД КЛИНИЧКА И НЕКЛИНИЧКА ПОПУЛАЦИЈА
}

\author{
Билјана Блажевска Стоилковска \\ Катерина Наумова
}

\section{Кратка содржина}

Целта на ова истражување е да се испита предложената факторска структура, релијабилноста и дискриминантната валидност на македонската верзија на една од најчесто користените мерки за тријажа и евалуација на третман. Испитаниците од двете групи се извлечени од две постоечки бази на податоци. Клиничкиот примерок $(\mathrm{N}=149,57 \%$ жени) се состои од испитаници со формално дијагностицирани ментални растројства од страна на психијатри, кои се тековно на вонхоспитален третман и од испитаници кои користат или имаат потреба од услуги за третман на нарушено ментално здравје, дијагностицирани од страна на психолози со примена на структурирано клиничко интервју. Сите дијагнози се поставени во согласност со критериумите на МКБ-10. Неклиничкиот примерок ( $\mathrm{N}=180,55 \%$ жени) се состои од лица кои не задоволуваат дијагностички критериуми за ниту едно ментално растројство или во последните шест месеци не користат/немаат потреба од услуги за третман на нарушено ментално здравје. За проверка на валидноста на конструктот беше применета конфирматорна факторска анализа. Резултатите ја поддржаа оригиналната структура од девет фактори во двата примероци, со прифатливи вредности на индексите на согласување на моделот. Покрај тоа, утврдена беше и висока внатрешна конзистентност на мерката. Дискриминантната валидност беше проверена преку споредба на двете групи испитаници во однос на деветте димензии на психопатолошки симптоми и трите глобални индекси на психичка вознемиреност. Инвентарот успешно ги диференцира двете групи во однос на сите поединечни супскали и трите општи индекси. Резултатите во целост упатуваат на задоволителни психометриски карактеристики на македонската верзија на Краткиот инвентар на симптоми.

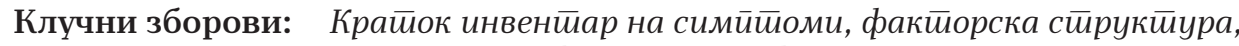

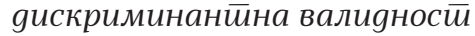

